ISSN 2413-0877 Volume 2 (2015) 662

The 3rd International Conference on Biological Science 2013

(The 3rd ICBS-2013)

\title{
EXPLORATION OF POTENTIAL PLANTS AS A BIO-INSECTICIDE AT ITS SURABAYA CAMPUS
}

\author{
Kristanti Indah Purwani, Dini Ermavitalini, Tutik Nurhidayati, Sri Nurhatika, \\ and Triono Bagus \\ Department of Biology \\ Faculty of Science \\ Institut Teknologi Sepuluh Nopember, Surabaya \\ *kristanti@bio.its.ac.id
}

\begin{abstract}
ITS Surabaya campus has a biodiversity potential, especially plants that can be utilized. Different types of plants have been known as a potential insecticide because they contain bioactive compounds, such as essential oils, saponins, tannins, alkaloids, phenolics, flavonoids, alkenes and these terpenoids. This research was a descriptive experimental, which aimed to explore the vegetation potential as plant-based insecticide or bio-insecticide. Tracking method to obtain plant leaves samples in ITS campus was used in this study. Leaf extracts were obtained using methanol solvents after the freeze-drying method that will change leaf into powder form. The extracts were then stored in the refrigerator and ready to be applied. Leaf dipping method was used as biological test. The test conducted on Spodoptera litura larvae that obtained from Balittas Malang. Larvae rearing trials were carried out in the Laboratory of Botany, Department of Biology ITS. The larvae examined were the third instar fed on fodder greens of leaf mustard. Toxicity effects of extract were observed from mortality of Spodoptera litura during 5 days. Ten plants species with bio-insecticide potential in this study were Ageratum conyzoides L., Crynum asiaticum L., Calotropis gigantea R., Eugenia cumini Merr., Eichornia crassipes, Crescentia cujete L., Nothopanax scutellarium Merr., Morinda citrifolia L., Azadirachta indica, and Lantana camara L.
\end{abstract}

Key words : Bio-insecticide, potential plants, Spodoptera litura

ISSN 2413-0877 (C) 2015 The Authors.

Published by KnowledgeE Publishing Services This is an open access article under the CC BY-NC-ND license (http://creativecommons.org/licenses/by-nc-nd/4.0)

Selection and Peer-review under responsibility of the 3rd ICBS-2013

Doi http://dx.doi.org/10.18502/kls.v2i1.242 